\title{
HAJDÚDOROG KORTÁRS TÁRSADALMI FOLYAMATAI
}

Szerző:

Soós Zsolt (Ph.D.)

Debreceni Egyetem (Magyarország)

A szerző e-mail címe:

soos.zs@ped.unideb.hu
Lektorok:

\author{
Rákó Erzsébet (Ph.D.) \\ Debreceni Egyetem (Magyarország) \\ Balázs-Földi Emese (Ph.D.) \\ Debreceni Egyetem (Magyarország) \\ ...és további két anonim lector
}

Soós, Zs.. (2020). Hajdúdorog kortárs társadalmi folyamatai. Különleges Bánásmód, 6. (3). 33-50. DOI $\underline{10.18458 / K B .2020 .3 .33}$

\begin{abstract}
Absztrakt
A Hajdúdorogon lefolytatott kutatásunk egy hosszabb, tíz elemből álló kutatássorozat része, amelyben elsősorban az ország kedvezőtlenebb helyzetű régióiban fekvő, kisebb lakosságszámú települések főbb társadalmi jellemzőinek, aktuális társadalmi folyamatainak a feltérképezésére törekszünk. A kutatás során alapvetően a helyi lakosok nézőpontjainak a megismerése és megjelenítése a célunk. A kutatási helyszínek megválasztásában döntő szempont volt, hogy e perifériális régiók kisebb településein meglehetősen kedvezőtlen szocio-demográfiai folyamatok zajlanak, ideértve különösen a települési lakosságszám csökkenését, az idősödést és a hátrányos helyzetû lakosság számarányának a növekedését. E folyamatok - amennyiben nem történnek jelentősebb változások - még a jelenleginél is kedvezőtlenebb jövőképet vetítenek előre. E kedvezőtlen szocio-demográfiai tendenciák egyértelmûen tetten érhetőek Hajdúdorogon. Ehhez kapcsolódóan a kutatás kiemelt céljának tekintettük az elvándorlásban leginkább érintett helyi fiatalság lehetőségeinek, céljainak és jövőképének, valamint a helyi közösségi kapcsolatoknak, ezen belül elsősorban a romák és a nem romák együttélési jellemzőinek a megismerését.
\end{abstract}

Kulcsszavak: a fiatalok és a romák helyzete, jövőkép

Diszciplina: szociológia

\section{Abstract}

\section{CONTEMPORARY SOCIAL PROCESSES IN HAJDÚDOROG}

Our research conducted in Hajdúdorog is a part of a longer, multiple part research series, in which we will identify the main social features and map the current social processes in the less populous settlements of the more deprived regions of the country in particular. Basically, the aim of our research is to understand and present the perspective of the local people. The decisive criterion for the selection of research sites was that the smaller settlements of these peripheral regions are subject to rather unfavourable socio-demographic processes, including in particular the decline in the population, aging and the increase in the share of disadvantaged population. These processes - unless there are significant changes - project an even more unfavourable vision of the future. The adverse socio-demographic processes described above are definitely observable in Hajdúdorog. Related to this, the primary objective of the research was to understand the opportunities, goals and vision of the local youth most affected by migration, as well as to recognize the local community relations and the characteristics of cohabitation of the Roma and non-Roma population in particular.

Keywords: the situation for young and roma people, the future vision

Discipline: sociology 


\section{Kutatási módszerek és eszközök}

A kutatásban többféle módszert alkalmaztunk, egyrészt megtörtént a településre vonatkozó társadalomstatisztikai adatok (pl. népességszám alakulása, stb.) elemző összegzése, valamint a térségre és a településre vonatkozó fontosabb dokumentumok (pl. településtörténeti adatok, fejlesztési tervek, stb.) áttekintése. A kutatás fő módszerének annak szemléletéhez igazodóan, vagyis a helybéliek nézőpontjának bemutatása érdekében - a szóbeli kikérdezést, ezen belül a részben strukturált egyéni interjút választottuk (Falus, é.n.). Előzetes feltérképezés, majd a hólabda módszer (Babbie, 1996) segítségével húsz egyéni interjút készítettünk el. Törekedtünk arra, hogy a válaszadók szociodemográfiai szempontból sokszínúek legyenek, s ezáltal a település lehetô legtöbb csoportjából csatornázzunk be véleményeket. Ebből következően a kérdezettek között voltak fiatalok, idősek, családosok, egyedülállók, roma, nem roma nemzetiséghez tartozók. A foglalkozást tekintve megkérdeztünk polgármestert, pedagógusokat, közmúvelődési és szociális szakembert, lelkészt és diakónust, ipari szakmunkást, kereskedőt, felszolgálót, fogyatékossággal élő gyermekét az otthonában gondozó, gyermekek otthongondozási díjában (a továbbiakban „GYOD”) részesülő lakost (1993 évi III. tv., 38ฐ), stb.

\section{Hajdúdorog}

A 8970 lakosnak otthont adó Hajdúdorog (KSH, 2019) Hajdú-Bihar megye északi határán, nagyobb városok, Hadúböszörmény, Hajdúnánás, valamint a már Szabolcs-Szatmár-Bereg megyében fekvő Újfehértó között terül el. Ezen elhelyezkedés alapvetően meghatározó a település életében, ahogy a város polgármestere (48 éves férfi) megfogalmazta: A település egykori „háttérországának” tekinthető tanyák megszűnésével, a nagyobb városok ölelésében, Hajdúdorognak napjainkban nincs vonzá- skörzete, „[...] mikö̈zben a környékbeli városok

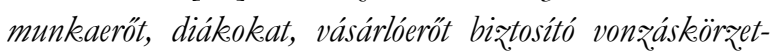
ként tekintenek Dorogra." A helyi lakosok jelentős része ténylegesen a környékbeli közép, vagy az akár kissé messzebb fekvő, magyarországi viszonylatban nagyvárosnak tekinthetô Debrecenben $(36 \mathrm{~km})$, vagy Nyíregyházán $(22 \mathrm{~km})$ dolgozik, tanul, intézi ügyeit, nagybevásárlását, vagy éppen szórakozik hétvégenként. Mindez azért is könnyen megoldható, mert a város fekvése alapvetően nem periférikus, akár Debrecenből is jó minőségú közúton érhető el, de az M3-as autópálya két lehajtója is viszonylag kisebb távolságra található. Debrecenbe, Hajdúnánásra és Hajdúböszörményre autóbuszjáratok is sűrűn közlekednek.

A település közszolgáltatásokkal való ellátottsága alapvetően megfelel egy átlagos helyzetû, hasonló nagyságú járásközponténak. Az óvodától a középiskoláig helyben elérhetóek a nevelési-oktatási intézmények, a szociális és gyermekjóléti alapszolgáltatások, ideértve a bölcsődét is. (A család- és gyermekjóléti szolgálat elsősorban a hátrányosabb helyzetű családoknak, ugyanakkor a bölcsőde többségében a középosztályba tartozó gyermekes családoknak nyújt segítséget, annak szolgáltatásaiból a hátrányos helyzetû családok gyermekei - bár a családi szocializáció és nevelés gyakori hiátusai miatt a korai fejlesztésre nagy szükségük lenne - rendszerint kevésbé részesülhetnek (Rákó, 2017). Emellett nagykötetszámú könyvtár, számos programot biztosító múvelődési ház, valamint heti egy alkalommal mozi is múködik a városban. Több kérdezett kiemelte azt is, hogy annak ellenére, hogy a település nem járásközpont, a kormányablak által biztosított szolgáltatások is helyben elérhetőek.

A Hajdúdorogon élők mindennapjait meghatározó másik jelentős sajátosság a hatalmas kiterjedtség. A település lakóira egyenként több mint egy hektár, kiemelkedően jó minőségi földterület jut, amiből következően a mezőgazdaság ma is alapvetően meghatározó jelentőségü, összességében 800 család foglalkozik mezőgazdasági termékek ter- 
mesztésével és értékesítésével, közülük mintegy százan főállásban, a többiek kiegészítő tevékenységként.

\section{Hajdúdorog története címszavakban}

A sajátos történeti fejlődés alapvetően meghatározta, s meghatározza ma is a település mindennapjait. A régészeti leletek alapján több mint 2000 éve lakják ezt a területet, amely azonban a török hódoltság, majd a 15 éves háború hatására egy idôszakban teljesen elnéptelenedett. Ezt követően Bocskay hajdúkat telepített le pusztabirtokán, akiknek jelentős kiváltságokat (pl. adómentesség) biztosított. A hajdúk letelepedése és az elmenekült lakosság visszaszivárgása miatt, s amiatt, hogy a kiváltságok kiterjedtek az itt élőkre, a népesség száma húsz év alatt városi méretûre duzzadt, s a település mezôvárosi rangot kapott. A környező tanyavilág központjaként funkcionáló, számos közigazgatási és oktatási szolgáltatást nyújtó város lakosságszáma 1940-ig folyamatosan, közel 12.000 fő́ig nőtt, amelyet egy azóta tartó - hullámvölgyekkel színesített csökkenés követett. Történeti szempontból további meghatározó tényező, hogy a környező településekkel ellentétben a lakosság döntő többsége nem református, hanem görög-katolikus vallású. E vallás helyi jelentőségét jól mutatja, hogy - döntően a hajdúdorogi hívek azon harcának eredményeképpen, amely során a honi görögkatolikusok a magyar nyelvű misézés engedélyezését akarták kiharcolni a római Pápától, s eközben más települések híveivel és papjaival közösen 1900-ban XIII. Pius pápáig is elzarándokoltak - 1912. június 8-án X. Piusz pápa a Christifideles Graeci bullájával megalapította a Hajdúdorogi Egyházmegyét (Komoróczy, 1971).

Ez a sajátos helyzet egyfajta védekezést, elzárkózást, s a környező településekkel szembeni, máig élő rivalizálást is eredményezett. Ennek egyik példája, hogy amikor a 2000-es évek elején jelentős pénzbeli ösztönzéssel próbálták elérni, hogy egyes szociális, közigazgatási, vagy oktatási szolgáltatáso- kat az azonos kistérségbe tartozó települések (Soós, 2009), jelen esetben Hajdúböszörmény, Hajdúnánás és Hajdúdorog közösen, valamely önkormányzat irányításával nyújtsanak, „Egyetlen önkormányzat sem volt hajlandó lemondani egyile saját szolgáltatásáról sem, még a jelentös többlettámogatásért cserébe sem." (polgármester, 48 éves férfi)

A szocializmus idôszaka szintén meghatározónak bizonyult a település életében. Egyrészról az erősen vallásos jelleg - legalábbis a lakosság jelentős része tekintetében - megmarad ezeben az években is. Interjúalanyaink többsége szerint a városban a vallásosságot a helyi pártvezetők jobban „megtűrték”, mint máshol. Egyetlen interjúalanyunk (46 éves nő, pedagógus) nyilatkozott ezzel ellentétesen azon saját élményéből fakadóan, hogy a hittanra járását nem nézték jó szemmel egykori tanárai. „Emiatt a radiator mellé is állitottak." Elmondása alapján azonban más hátránya nem származott ebből. Ugyanakkor - a középkorú és az idősebb kérdezettek elmondása alapján - a korszak pártvezetői sokat tettek azért, hogy ipari üzemeket telepítsenek Hajdúdorogra, s ezáltal újabb munkalehetôségeket teremtsenek a mezőgazdasági jellegú városban. A szocializmus utolsó két évtizedét a 40 évesnél idősebb interjúalanyok többsége kedvező időszakként élte, s ítéli meg. Erre utaló jel az is, hogy a rendszerváltás első szabad választásán az egykori tanácselnököt választották meg polgármesternek.

Az, hogy a település egykor kiváltságokkal bírt, központi szerepet is betöltött, jelentős vallási eredményeket ért el, viszont az elmúlt évtizedekben a lakosságszám jelentôsen csökkent, az ipari üzemek többsége megszűnt, az idős és a halmozottan helyzetű lakosság, köztük a hátrányos helyzetû roma lakosság aránya nőtt, rányomja a bélyegét a helyiek hangulatára, a település helyi megítélésére. Ahogy egyik interjúalanyunk fogalmazott: , $A$ depresszió, a viláafájdalom jellemæó. [...] Hogy mi miatt? Sžerintem a rendszerváltás sikertelensége miatt." (57 éves nő, közmûvelődési szakember) Összességében in- 
terjúalanyaink többsége kedvezőtlennek ítéli meg a város jelenét, és jövőbeni lehetőségeit egyaránt.

A környező településektől évszázadok óta különböző vallás, az ebből is eredő elzárkózás némiképpen az általunk vizsgált többi településnél is nagyobb zárkózottságot eredményezett napjainkra, amikor a technológiai eszközök fejlődése és a társadalmi folyamatok eredményeképpen az egész országban egyre zárkózottabbá válnak az emberek (Albert és Dávid, 2018).

E másokkal szembeni bizalmatlanságra, a részben ebből eredő zárkó-zottságra példa, hogy a helyi család- és gyermek-jóléti szolgálat munkatársa, aki évtizedekkel ezelőtt költözött a településre elmondta, úgy érzi, évekig nehezen fogadták el, de talán még ma sem teljesen, azért is volt nehéz számára itt élni. Napjainkban pedig már úgy gondolja, úgy fogalmazott, hogy: „Úgy vagyok vele, hogy ha bezárom az ajtót, jól érzem magam a családommal, akkor mindegy hol élek." (49 éves nó) A településen élő, itt született interjúalanyaink többsége pedig arról számolt be, hogy napjainkban nem jellemző a közösségi élet, még csak a szomszédokra sem jellemzó, hogy szorosabban tartanák egymással a kapcsolatot, inkább mindenki bezárkózik.

\section{A fiatalok helyzetéröl}

Egységes hajdúdorogi fiatalságról nem beszélhetünk, a családi háttér itt ugyanúgy jelentősen befolyásolja a gyermekek és fiatalok tanulmányi előmenetelét és későbbi életlehetőségeit, mint az ország más területein (Lannert, 2018).

A Hajdúdorogon élő fiatalok kapcsán (is) jól kirajzolódik az a kép, hogy egy település, a helyi vezetők, a közintézmények munkatársai, s maga a helyi közösség tud tenni azért - példának okáért kiépült közintézményrendszer múködtetésével, vagy szabadidôs lehetőségek (skate park, darts klub) és programok biztosításával - hogy a fiatalok jobban érezzék magukat, ezáltal jobban sajátjuké- nak érezzék a települést. Ugyanakkor a magyarországi, sőt, az egész régióra és az Európai Unió egészére érvényes globális tendenciák erősebbnek bizonyulnak e helyi kezdeményezéseknél. (EBRD, 2019) A jobb munka és kereseti lehetőségek, a szolgáltatások szélesebb köre, a szabadidő eltöltésének nagyobb választéka, a nyüzsgőbb élet, és a szoros személyes (családi, szomszédsági stb.) kontroll hiányából eredő nagyobb szabadság egyre inkább városokba, ezen belül is nagyvárosokba vonzza a fiatalabb nemzedéket, különösen annak képzettebb tagjait. Egyes elemzők szerint mindez a kistelepülések megállíthatatlannak tűnő eltűnését, a lakosság döntő többségének, vagy akár egészének nagyvárosokba tömörülését eredményezheti (EBRD, 2019).

E folyamatokat helyi szinten az alábbiakban leírtak szerint fogalmazták meg:

- „A fiataloknak a tudás megszerzése hellyel-közzel a telepuilés végét jelenti [...] a XXI. század értelmiségét elveszitite a kistelepuilesese, Budapest, Debrecen és Nyugat-Európa profitál belóliik. Eqáltal nemcsake a település, hanem a család megtartó ereje is fellazul." (48 éves férfi, polgármester)

- „Eltünt a 20-30 közötti korosztály. Aki megszerez. egy diplomát, annak itt Dorogon nincs már lehetöség." (46 éves férfi, szakmunkás)

- „A fó motiváció ma már a fizetés. Már az általános iskolások is ąt mondják: "Elmegyek külföldre dolgozni Pistabá.«" (56 éves férfi, közművelődési szakember)

- „Ez a kisváros túl visszafogott szerintem.” (22 éves nő, egyetemi hallgató)

Ugyanakkor az egyik megkérdezett helyi lelkész úgy tapasztalja, hogy bár a globális tendenciák itt is hatnak, azonban ,[...] kevésbé tudták megtépázni a hajdúdorogi családokat." (52 éves férfi, lelkész) A házasságot kötő fiatalok jelentős része mondta azt, hogy ugyan átmenetileg elköltözik nagyvárosba, 
vagy külföldre, de később vissza szeretne költözni, vagy eleve Hajdúdorogon tervezi a jövőjét.

\section{A település erősségei, megtartó erejének el- emei}

A kisváros nyugalma: ellentétben a nagyvárosokkal a település nem zajos, a levegó nem szennyezett, az élet nem annyira „rohanós”. „Én zárkózott vagyok, ez a csendesebb élet, ami itt van Dorogon, nekem megfeleló"” (46 éves férfi, szakmunkás.) „Az elönye, hogy meg tud maradni egy jó, élhetó, csendes kisvárosnak.." (59 éves nő, pedagógus)

Helyben élnek a családtagok, rokonok, barátok, ismerôsök. Van kivel beszélgetni, nem magányosak az emberek, s van kire számítani. „Nem idegenek az emberek [...] a szomszédok ismerik egymást [...] közvetlenek az, emberek, ha segitségre szorul valaki, akkor segitenek egymásnak." (42 éves roma nő, GYOD-ban részesül.) „Ez egy város, de azért kisváros, az azonos korosztályba tartozók ismerik egymást, nem idegenként vannake, szóba állnak egymással." (48 éves férfi, polgármester) „Itt még a fák is kösqönnek nekem, ha végig megyek az utcán.” (57 éves nő, könyvtáros)

Közintézményekkel, szolgáltatásokkal való ellátottság. „Minden elérhetô itt szinte, ami egy családnak szüleséges.” (38 éves nő, óvodapedagógus) „Hajdúdorog nem járásszéḱkhely, mégis sikerült kiharcolni, hogy helyben müködjön kormányablak, vagyis helyben lehessen elintézni a bivatalos ügyek döntö többségét." (48 éves férfi, polgármester) (Ez egyben a helyiek elszántságára, és a környezó településekkel való rivalizálásra is példa.)

A településen olcsók az ingatlanok, így lehetőség adódik az életkezdésre, vagy akár a népességszám majdani növekedésére. "Az utóbbi idóben költöztek is ide, mert itt nagyon olcsók az ingatlanok." (46 éves férfi, szakmunkás)
Közmunkaprogramok biztosítása a rosszabb helyzetû lakosság számára, amely egyrészt megélhetést biztosít, másrészt abban is segített, hogy a helyben egymástól nagyon elszeparáltan élő roma és nem roma lakosság megismerje egymást, és némiképp csökkenjenek a társadalmi távolságok. „, $A$ közmunkában az önkormányzati földeken dolgoznak [...] például paprikatermesztés van [...] a roma családok is dolgoznak. (38 éves nó, óvodapedagógus) „A közmunkaprogramban el lehet helyezkedni, lehet pénzt keresni, ha nem is sokat, de a megélhetés alapját [...] meg 800 fö részesül szociális étkętetésben, akiknek nagyrésze roma, szóval már nem kell a létfenntartás miatt bünözni, és csökkent is a bünözés." (46 éves férfi, szakmunkás) „A közmunkaprogramban együtt dolgoztak a romák és a nem romák. Összesimultak ebben az idöszakban [...] Már nem cigány, hanem a munkatársam." (56 éves férfi, közművelődési szakember)

Lokálpatriotizmus, a településhez való lelki kötődés. „A fiatalok egy része erösebben kötódik ide, itt maradnak, és hozzájuk kötódnek a helyi kezdeményezések, példaul a darts klub." (56 éves férfi, közművelődési szakember) ,A fiatalok többen maradnának itt, ha lennének lebetöségek [...] mert sokan erösebben kötödnek ide [...] ide jártak iskolába, itt vannak a barátaik, meg nem is tudom, ežt nehéz. megmagyarázni." (20 éves férfi, egyetemista)

Az eddig vizsgált, alapvetően peremhelyzetủ településekkel ellentétben, sokan emelték ki pozitívumként a város jó megközelíthetőségét, azt, hogy közel van más nagyobb városokhoz, s a buszközlekedés is kellően gyakori és gyors Hajdúnánásra, Hajdúböszörménybe és Debrecenbe egyaránt.

További jelentős előny a helyi fiatalság tudatos segitése, mégpedig úgy, hogy az ifjúság igényeire építenek, a helyi fiatalok kezdeményezéseit próbálják felkarolni. Ilyen, a helyi fiatalok részérôl konkrétan megfogalmazott igényre reagálva épült skate park, amely ma is kihasznált, vagy szerzett be a helyi mûvelődési ház darts eszközöket. Ez utóbbi 
kapcsán kiemelendő, hogy napjainkban már darts klub múködik a városban, s 2019 nyarán megrendezték az első városi és megyei bajnokságot is. , $A$ z alulról jövö kezdeményezések életképesek, amíg bennük van az akkumulator" (Vagyis az adott kezdeményezés iránt elhivatott ember/emberek. - Értelmező közbevetés tôlem.) [...] A fiatalok nem szeretik azt, ha megmondják nekik, hogy ezt akarod csinálni." (46 éves férfi, polgármester)

\section{Hajdúdorog gyengeségei - miért nem vonzó a település a fiataloknak}

A település visszafejlődése, elöregedése, a hátrányos helyzetû lakosság számarányának növekedése. Ahogy a korábbiakban arról szó esett, Hajdúdorog lakosságszáma 1940-tól szinte folyamatosan csökken. A kérdezettek, közöttük a polgármester elmondása alapján a tényleges lakosságszám maximum 8500 fő lehet, ugyanis a településen közel 300 ház áll üresen. Ezek - döntően a középkorosztályba tartozó - tulajdonosainak a többsége ugyan hivatalosan Hajdúdorogon, de valójában külföldön él és dolgozik. Ennek egyik fó oka az, hogy ,[...] nagyszámban estek bele a belyiek is a devizabitel csapdajá$b a$ ", (48 éves férfi, polgármester) s ez volt az egyetlen lehetőségük arra, hogy a drasztikusan megemelkedő lakáshitel részleteit törleszteni tudják. Ugyanakkor úgy tűnik, ezen emberek, családok jó része már nem fog visszaköltözni, sőt, van már egy olyan család is, amelyben a nagyszülők is kiköltöztek Angliába, s az ott élő magyar családok gyermekeire vigyáznak. „Amíg a nagymama vigyáz a gyerekekre, a nagypapa vágja a füvet e családoknál." (48 éves férfi, polgármester)

Az interjúalanyok beszámolói alapján ugyanakkor az idősek, a hátrányos, vagy halmozottan hátrányos helyzetúek, köztük a romák többsége is helyben marad. Sőt, az utóbbi néhány évben, 2015-tôl kismértékben, 193 fốvel nôtt is a lakosságszám (KSH, 2019). A polgármester elmondása szerint e növe- kedés részben amiatt történt, mert az olcsó lakásokba a közeli városokban dolgozó, de rosszabb anyagi lehetőségekkel rendelkező családok költöztek. Azonban még inkább amiatt, mert a környébeli nagyobb városokból idősek költöznek a településre. A kolléganómék is kikö̈ltöztek (külföldre -értelmező közbevetés a szerzőtőll), nem volt más válasz̨ásuk a devizabitel miatt [...] itt programtervezón volt, kint takarit. A férjének autómosó vállalkozása van, már nem jönnek. vissza [...] Ma már könnyü küllföldre menni, rengeteg magyar él kint, sok az ismerós, barát, még kezdótóke se kell." (56 éves férfi, múvelődési szakember) „E₹ a település teljesen el fog öregedni." (20 éves férfi, egyetemi hallgató) „Hajdúdorog tíz év múlva? Ez egy cigány település lesz:” (66 éves férfi, nyugdijas) „Leginkább az idôsek költöznek ki Debrecenböl, Bösqörményból, 20-30 millióért eladják a házaikat, itt vesznek egyet tízért, és a többiböl a gyerekeiket támogatják." (48 éves férfi, polgármester)

A munkalehetőségek, különösen a minőségi munkalehetőségek hiánya.

Hajdúdorog lakosságszámából, s abból adódóan, hogy vonzáskörzettel sem rendelkezik, vagyis zömében ténylegesen csak az itt élőknek nyújtanak szolgáltatásokat, korlátozottak a munkalehetőségek, különösen a diplomás álláslehetőségek. E városra is jellemző, mint sok más hasonló adottságú településre, hogy a közintézmények diplomát igénylő álláslehetőségei - ahogyan a kérdezettek megfogalmazták „szinte kihalásos alapon” múködnek. Emellett, mivel ipari vállalkozás is alig van, a szakmunkások is kevéssé tudnak helyben munkát vállalni. Ebből következően a diplomás, de még a szakmával rendelkező fiataloknak is kevés lehetősége adódik az elhelyezkedésre. "Nincs itt semmi, nincs munkalehetóség és nincs normális szórakozási lehetöség." (19 éves nő, felszolgáló) „Aki megszerez egy diplomát, annak itt Dorogon nincs már lebetöség $[. .$.$] a rokonságban is vannak$ fiatalok, sejtbiológus, gyógytornász. meg mérnök, ök is csak Egerbe, meg Debrecenbe tudtak elhelyezkedni [...] Azok maradnak itt, akik a szülöktól átveszik a földet, vagy a vállalkozást. [...] 800 bejegyzett östermelo" van. 50-100fó, 
aki teljesen a földmüvelésböl él. Még a közigazgatásban is van egyfajta utódlás, aki ott dolgozilk, annak a gyereke is jó eséllyel hasonlót fog tanulni, és könnyebben talál is majd munkát, vagy átvesæi a szülö helyét. 20-30\%-a az állásoknak igy öröklódik" (46 éves férfi, szakmunkás) „Például, ha valaki elmegy atomkutatónak, azáltal eldöntötte, hogy nem akar itt maradni, mehet Paksra, Debrecenbe, vagy Budapestre [...] 60-70 föt támogat az önkormányzat Bursa Hungarica ösztöndíjal, ebböl maximum öt fó fog hazajönni, egy-két jogászra, egy-két orvosra van szü̈kség csak." [...] Gyakran megkeresnek, nagyon kedves fiatal emberek, hogy elhelyezkednének szociálpedagógus végzettséggel [...] de a családsegitöben az átlagéletkor 42 év, oda 20 évig nem kell ember [...] az egész képzési rendszert át kellene gondolni. [...] Aki szakemát tanul, nem Dorognak, hanem a debreceni cégeknek termelik a szakembereket [...] van egy-két vállalkozó helyben, de nem tud versenyképes bért fizetni." (48 éves férfi, polgármester)

A magánszolgáltatások hiánya, szűkössége.,,Jó lenne egy nagy bevásárlóközpont, ami olcsóbb, a nagycsaládosoknak [...] meg fejlesztóppedagógiai csoport a helyi iskolában [...] csak Hajdúböszörményben lehet a fejlesz̨ö́pedagógia problémát megoldani." (42 éves roma nó, GYOD-ban részesül) „Dorog túl kicsi és túl nagy egyszerre. Például a néptáncoktatás. Elég nagy abhoz, bogy van rá igény, de túl kicsi abhoz, hogy fenntartható legyen. Böszörményben a néptáncosok 20 squázaléka dorogi [...] Egy nagybevásárláshoz el kell menni máshová." (46 éves férfi, szakmunkás) „Nagyvárosban több minden van, több bolt, több helyre el lehet menni." (19 éves nő, kereskedő)

A kulturált szórakozási lehetôségek, egyáltalán a szórakozási és szabadidő eltöltési lehetőségek korlátozottsága. „Az egész városban nincs még egy cukrászda sem, abová be lehetne ülni [...] volt egy, de az is bezárt.” (38 éves nő, óvodapedagógus) „Szerintem szüleség lenne itt egy cukrászdára, meg egy uszodára [...] meg amúgy nincs semmi színvonalas szórakozási lebetöség bétvégén.” (19 éves férfi, egyetemi hallgató) „Nincs normális szórakozási lehetöség [...] ha Nyiregybázán elme- gyek bulizni, 22.00-kor is megy bus?, meg hajnalban is bazafelé. Itt meg megoldod, abogy tudod." (19 éves nő, kereskedő) „Sok programot igyekeznek szervezni, de inkább a gyerekes családoknak. A fiatalok kiesnek ebböl. Diszleó van a tiniknek. A 20-25 éves korosztály Nánásra, vagy Debrecenbe jár inkább [...] Az esti szórakozóbelyek itt inkább a körépiskolásoknak szólnak." (22 éves nő, egyetemista)

A kistelepülési környezetből adódóan ismerik, és „ki is beszélik egymást” a helyiek. „Mindenki ismer mindenkit, mindenki pletykál mindenkiröl." (19 éves nő, felszolgáló)

E negatív hatások, és a korábbiakban említett globális tendenciák (EBRD, 2019) a hajdúdorogi fiatalok jövőképét is alapvetően befolyásolják. Az általunk megkérdezett fiatalok közül egyik sem helyben képzeli el a jövőjét. Hárman Debrecenben, egy kérdezett vagy Nyíregyházán, vagy külföldön, egy pedig mindenképpen külföldön szeretne élni. A korábbiakban felsorolt okok mellett ebben szerepet játszik a „kalandvágy”, és az elsősorban ma már a közösségi médián keresztül érvényesülő társadalmi befolyásolás/nyomás is. Végül egyik kérdezett azt is kiemelte, úgy véli, Magyarországon az emberek általában nagyon negatív attitúddel rendelkeznek, s nem szeretné, ha a leendő gyermekei ilyen közegben nőnének fel, továbbá az oktatás és az egészségügyi ellátás színvonalát is rossznak tartja. „Szrerintem mindenkiben felmerül, bogy elmegy nagyobb városba, vagy hogy kimegy (külföldre - értelmező közbevetés a szerzőtől.) [...] Mert a változatosság kell [...] Hogy miért? Mert mindenki ąt mondja, bogy az. kell.” (19 éves nő, felszolgáló) „Miért éppen Németország? Kalandvágy, uj ország, új emberek megismerése. Jobb kereseti lehetóség. Mi szeretünk utazni, a mai fizetésekböl ezt nem tudjuk megvalósitani [...] Meg ha lesz gyermekem, ott nem bat majd rá a magyar társadalom [...] rossz. az. oktatás, rossz az egészségügyi ellátás színvonala." (22 éves nő, egyetemi hallgató) 


\section{Roma-nem roma együttélés}

Hajdúdorognak az adott térségtől eltérő vallástörténeti fejlődése, vélhetően jelentős részben ehhez kapcsolódóan az itt élőknek a környező települések más vallású lakóival szembeni bizalmatlansága, tôlük való elzárkózása, a település határain belül is érvényesül. A helyi romák különbözősége, a többségi lakosságtól részben eltérô életmódja ugyanúgy elzárkózást, bizalmatlanságot, esetenként elítélést, megvetést eredményez. „Simán kifejezi bárki a nem tetszését a romákekal kapcsolatban, akár trágár módon is." (20 éves férfi, egyetemista) Az elkülönülés szemmel látható jele a település két roma szegregátuma, valamint az, hogy romák csak a település olyan részein élnek nem romák szomszédságában, ahol a nem roma lakosság is jellemzően hátrányos helyzetû. Ám még ez a fajta szomszédsági viszony is ritka Hajdúdorogon. Ennek egyik oka az, hogy ,„[...] ha egy cigány család egy utcába beköltözik, onnan elmenekülnek a magyarok." (46 éves férfi, szakmunkás) Interjúalanyaink jelentős része ennek egyik okát „a múltból gyökerezơo elöitéletekben”, a másikat pedig abban látja, hogy a roma családok rossz példát mutatnak a nem roma családok gyermekeinek, mivel már a roma gyerekek is dohányoznak, csúnyán beszélnek, agresszívak, valamint nagyon korán elkezdenek szexuális életet élni. A roma nem roma elkülönülés másik oka az interjúalanyok szerint (ideértve roma származású kérdezettet is) az, hogy maguk a romák is szívesebben élnek roma közösségben, mint „magyarok” szomszédságában. Vagyis az elzárkózás ma már kölcsönösnek tűnik.

Az elkülönülés másik példája az, hogy a településen egymás mellett múködik egy egyházi, és egy állami fenntartású általános iskola, s az előbbibe szinte kizárólag nem roma származású gyerekek, míg a másikba napjainkban már többségében roma gyermekek járnak. A megkérdezett helyi diakónus (62 éves férfi), illetve egyik vallásos interjúalanyunk (38 éves nó, óvodapedagógus) is azt emelte ki, hogy ez az oktatási szegregáció nem tudatosan tervezett és irányított folyamat eredményeképpen ala- kult ki, hanem azt „[...] a szülök csinálják.” (62 éves férfi, diakónus, férfi) Mégpedig azáltal, hogy a családok egy része, ideértve a roma családokat, egyszerűen nem akarja teljesíteni az egyházi iskola egyházi jellegú követelményrendszerét, például az egyházi szentségek (elsősorban az egyházi házasság) felvételét, valamint esetenként a gyermekek vallási szertartásra járatását sem. Ugyanakkor tudható az is, hogy a jelentős vallási élet ellenére, számos szülő éppen amiatt teljesíti e követelményrendszert, hogy gyermeke abba az iskolába kerülhessen, amelybe alig járnak roma gyerekek. Két fiatal interjúalanyunk is nehezményezte, hogy az egyházi általános iskolába „akaratuk ellenére” kötelező volt misére járniuk, amit „túlrásnak tartanak”. Vagyis, ha nem is célzott, és tudatos szegregációról van szó, a két iskola adott módon való mûködtetése lehetőséget ad a szegregált oktatásra, ami meg is valósul Hajdúdorogon.

A gyermekkortól induló, és az életet végig kísérő elkülönülés, s az egymás nem ismeréséből kialakuló kölcsönös elóitélet (Forgas, 2007) jelenléte érzékelhető a településen. Ugyanakkor interjúalanyaink többsége ennek kapcsán úgy nyilatkozott, hogy helyben kevéssé okoz problémát a „cigánykérdés”, mivel a romák és a nem romák között kevéssé van interakció, kapcsolat, így konfliktusok sincsenek, egyszerúen „,[...] csak elélnek egymás mellett.” (19 éves férfi, egyetemi hallgató) Több interjúalany azt is kiemelte, hogy a múltból, családi sérelmekből eredő évtizedes konfliktusok inkább a két szegregátum roma lakosai között vannak.

Csakhogy ezen elkülönülés súlyos következménye, hogy a szegregátumban élők, ami kiemelten érvényes az egyik települési szegregátumra, beleragadnak a mélyszegénység, vagyis a kilátástalan nyomor generációról-generációra hagyományozódó állapotába.

A mindennapi élet szervezése kapcsán kevéssé látnak megfelelô mintát, követendô példát, s bár vannak segítő beavatkozások, de kellő mértékủ, s kellően hatásos segítségre kevéssé számíthatnak. 
Így e családok jelentős része tekintetében nincs, ami megtörné ezt a kedvezôtlen újratermelódési ciklust.

A romák és a nem romák viszonyáról, a helyiek felelősségérôl a roma pasztorációval megbízott, aktív telepi segítôi munkát végző diakónus (62 éves férfi) - aki e munkát jelentős részben egyedül, segítôi team nélkül látja el, ami amellett, hogy óriási terhet jelent, a beavatkozás hatásosságának is szúkösebb keretet szab - a következőket mondta: „A magyarok általánosságban elturite öket. Nem foglalkoznake velük, nem jellemzó, hogy segitenék az én munkámat, és egyáltalán az, hogy belássák, hogy ez, egy nagyon nagy kérdés itt Dorog számára, meg abol roma lakosság van. Hogy mi történik majd egy nap, amikor az unokámnak együtt kell élnie a romákkal, hogy ezt a munkát már most kell, el kell kezdeni [...] S ami mondjuk itt Dorogon kimaradt, teljesen elmaradt az iskolán kivuili társadalmi munka, vagy mindegy, bogy minek nevezzük, szociális munkának. Ezt elfelejtették az itteni emberek."

Azt, hogy - a fentiekből is következően - mi jellemzi, különösen az egyik szegregátumban lakó romák életét, az alábbiak szerint látják a megkérdezett, e szegregátumban élőkkel kapcsolatba kerülö emberek: [...] kimentem a telepre [...] ott 60-as évekbeli állapotokat találtam, nagyon leszegényedett, és nagyon magukera bagyott embereket [...] Az általános képlet az. volt, hogy csak ágy van, nincsen szekerény, nincs hol tisztálkodni, ebböl adódott a helyzet, hogy ęt akkor valahogy pótolni kell. [...] Vannak olyan lakások, abol 25-en élnek, [...] minden helyiségben többen laknak." (62 éves férfi, diakónus) „Sok a probléma. Sok ember él egy bázban, abol nincs fürdószoba. [...] nem fontos nekik a gyerekek tanittatása, és hogy a gyerekeket jól öltöztessék [...] Problémák vannak az óvodai, iskolai hiányzással, nem akarják engedni oviba a gyereket. Elhanyagolás van, meg higiénés problémák. Jellemró a gyerekek nem megfeleló táplálása, a nagy kos\%. Kiemelt terület gyermekvédelmi szempontból. (22 éves nō, egyetemi hallgató) (A kér- dezett - szociálpedagógia szakos hallgatóként egyik szakmai gyakorlatát a helyi család- és gyermekjóléti szolgálatban töltötte, ekkor tapasztalta a leírtakat.)

A helyi család- és gyermekjóléti szolgálat munkatársa (49 éves nó) az alábbiakat sorolta fel e családokban problémaként:

- nem tartják tisztán a lakást, az udvart, sokan nem művelik a kertjüket sem,

- sok családnál „lopják az áramot” szabálytalan vételezéssel,

- rossz a pénzbeosztás,

- egyoldalú a táplálkozás,

- nem jellemző rájuk az öngondoskodás, mint a nagyszüleinknél volt, például nem tartanak csirkét,

- a romák nem szeretnek főzni, elterjedt a gyorsételek rendelése, a pizzarendelés,

- korai házasság és gyermekvállalás,

- nem motiváltak a tanulásra, csak 1\% fejezi be a középiskolát,

- ha valamiben sikert ér el a gyerek, pl. sakkozás, sport, a szülők csak akkor értékelik, ha pénz jár érte, csak a pénzzel lehet ôket motiválni. Emiatt például nagyon sikeres, országos második helyezést elért gyermek már abbahagyta a sakkozást.

E felsorolásból egy jól ismert nyomortelepi kép bontakozik ki: kedvezőtlenek az életfeltételek, az életlehetôségek, és ehhez igazodik az itt élő családok életmódja is. A mélyszegénységben, az egyik napról a másikra élố családok életében aligha lehet más a cél, mint az alapvető emberi fizikai szükségletek kielégítése. Ma már jól ismert tudományos teória (Maslow, 1970), hogy ameddig valakinek az alapvetô szükségletei tartósan nincsenek kielégítve, magasabb rendû emberi szükségleteinek: a kognitív szükségletenek, a szépség, az esztétikai iránti, vagy éppen az önmagvalósítási szükségletnek a kielégítésére nem tud törekedni. 
Kirajzolódik azonban egy másik kép is, tudni illik a szegregátumokban élô roma családoknak a helyiek általi megítélése, amelynek talán a legfóbb eleme a romák önhibájának a hangsúlyozása. Annak a nehezményezése, hogy nem tartanak haszonállatokat, nem szívesen főznek, sőt, még pizzát is rendelnek. Mindezt úgy, hogy a nem romák döntő többsége sem tart ma már haszonállatokat, és aligha számít ma már különlegesnek, vagy kivételnek egy pizza megrendelése. Vagyis e tekintetben érvényesül egyfajta kettôs megítélés, ami a nem romáknál természetes és elfogadható, az a romák esetében helytelen magatartás.

A megkérdezett szociális szakember és a pedagógusok egyaránt jól érzékelik, látják azt, hogy a hagyományos nevelési, illetve a szóbeli tanácsadáson, a klasszikus típusú felvilágosításon alapuló módszerek kevéssé eredményesek e családok esetében. „Hiába vannak felvilágositó programok, nincs hasznuk, mert a saját szocializációs szinterïkben nem ęt látják." - fogalmazta meg a család- és gyermekjóléti szolgálat munkatársa (49 éves nô). A helyi szint mellett, országos szinten is tapasztalható, hogy a tizenévesek, ezen belül kiemelten a halmozottan hátrányos helyzetű nők körében, az elmúlt években jelentôsen, mintegy negyedével nôtt a szülések száma, miközben a 20-34 év közötti korosztályokban alapvetően stagnált a gyermekvállalási hajlandóság (Kapitány és Spéder, 2018). Tehát ismételten kiemelhető, hogy a családból, a környezetből gyakran kedvezőtlen, a nyomor újratermelődésének irányába ható mintát kapnak e gyermekek, miközben nem kapnak kellő motivációt - példának okáért - a kiemelkedést elősegítő tanulásra, sportra stb. Csakhogy nem „csupán” a szülői motiváció és megfelelő nevelési képesség és tudás hiányos, hanem úgy túnik - legalábbis jelentôs részben - az a segítő pedagógus, és/vagy szociális szakember is hiányzik, aki tudná segíteni a szülőket a gyermeknevelésben, aki leült volna az országos sikereket elért sakkozó gyermek és szülei mellé, s aki segített volna meggyőzni őket a folytatás fontosságáról.
Ennek hiányával kapcsolatban a megkérdezett szociális szakember (49 éves nó) egyrészt a pedagógusok fásultságát, ami a sok energiabefektetés ellenére kevés eredménnyel járó munkára vezethető vissza, másrészt az ismeret hiányát nevezte meg fó okként, vagyis azt, hogy: „A pedagógusok nem ismerik a romákat, igy nem tudnak rájuk hatni." A helyi családés gyermekjóléti szolgálat esetében pedig az elégtelen kapacitásokban látja a fô okot.

Abban, hogy a szolgálat nyolc munkatársa idejének a jelentôs részét leköti a fô feladatok ellátása. Az intézmény-vezetô (49 éves nő) által kiemelt feladatok alapvetően az alábbiak:

1) A települési támogatás odaítélése kapcsán annak ellenőrzése, hogy a szociális segélyt kérő romák rendben tarják-e a portájukat. "Azt is fontos elmondani, hogy azok az önkormányzat által nyúitott telepuilési támogatások, a rendkivuili és a rendszeres támogatási formák, ha valaki ezele közül valamilyen ellátást igényel, akekor szü̈kéeges, bogy jelentkerzeren nálunk. Itt egy együttmüködési megállapodást kötünk, amivel havonta, tehát kapnak egy ilyen kis könyvet, és havonta jelentkezniük kell egy évig. És akkor ilyenkor az élethelyzetükröl, hogy esetlegesen valami javulás bekövetkezett-e [...] Az a lényege a dolognak, bogy figyelemmel kisérjü̈k az adott egyént, hogy bonnan indult, mièrt szorult erre a támogatásra, és hová jutott. De azért eźt a támogatás odaitélését megelóri egy környezettanulmány, amit az önkormányzatnak egy bivatali dolgozója, illetve nekem két kollégám végez el havonta egyszer [...] Ez. egy többoldalas körmyezettanulmány [...] ami helyi rendeletben is megjelenik, bogy nagyon fontos a környezet rendben tartása. Tehát az, hogy a jövedelmi viszonyai alapján jogosult arra a támogatásnak az odaitélésére, ngye ezt a szociális bizottság dönti el, az egy dolog. De a környezetnek a rendben tartása, tebát itt az udvar, a ház rendben tartása, illetve a külsö környezetben nagyon fontos a₹, hogy csatorna megoldott legyen, vagy a, ugye, ha valakinek nincs fürdöszobája ak.kor a kinti WC, az, hogy az udvaron ugye ne halmozzanak fel szemetet. Esetlegesen kerítés, tebát körbe keritve, és hogyha ilyen biányosságok. vannak, ake.kor ugye felszólitjuk, bogy ezt rendezze, és csak abban az esetben kapbatja meg." (Fontosnak tartom kiemelni, hogy meg- 
lehetősen aggályos, hogy ha valaki anyagi helyzete miatt segítségre szorul, számára a helyi szociális bizottság emiatt támogatást szavaz meg, azt csak akkor kaphatja meg, ha a rendszerint jelentôs, akár több százezres költséggel járó csatorna- és/vagy kerítés kialakítást elvégzi. E gyakorlat - magától értetődően - alapvetően ellentmond a szociális munka szakmai és etikai alapelveinek. (3Sz, 2016)

2) Adósságkezelésben, ehhez kapcsolódóan közmûszámlák törlesztésében való segítés, továbbá a szabálytalan áramvételezés ellenőrzése, a szabályos áramvételezés megoldása előre fizetős órákkal. „Van adósságkezelési tanácsadás, egy kollégám végzi [...] Az, ami jellemzó, a villany, az, okozott problémát, de elég jól alakult már a helyzet, mert azért azt tudni kell, hogy azért folyamatosan ellenôrizzük azt is, bogy mondjuk szabálytalanul vételeznek áramot. Van hatósági bejárás a járási bivatal munkatársaival együtt [...] Jönnek a sz̧abálysértési hatóságtól, a gyámbatóság, a családsegitón és a rendôrség munkatársaival [...] Nyilvánvalóan a szolgáltatónak okoznak azzal kárt, hogyha lopják az áramot [...] de azért ez egy életveszélyes mutatvány [...] Kollégáim ezt nem laikusként, hanem az egyik kollegámnak van szakemája, basonló végzettsége, tehát felnér, és azonnal észreveszi, és ugye ezt szóvá teszi [...] Illetve ugye az áramszolgáltatók keresnek minket, ha már nagyon-nagyon magas az felhalmozott adósság [...] és akkeor elbatároztuk, [...] hogy megpróbábjuk minél kevesebbért beköttetni ezeket a kártyás fogyasztásméröket [...] Van egy elvárás is amellett, hogy vegyék komolyan $[\ldots]$ de bogy ennek milyen vonzatai vannak, tehát ez. mit fog maga után vonzani, tehát ugye, ha mondjuk a szankciót nézzïle, a büntetést, akeor hogyha megbüntetik, akkor nyilván ąt a családtámogatási ellatásból kell elvenni, a gyerekeketöl kell elvenni. Ha ugye letöltendö börtönbüntetésre itélike, akeor megint csak a kiskorú az, aki ebbe ugye bátrányt szenved. Mert ugye, ba a törvényes képviselö nincs jelen, akekor a gyereket el kell helyezni, ha pénzbirság van, akkor megint a kiskorú veszélyeztetése áll fenn, és annak ugye vannak folyamatai, hogy milyen szankciókat von maga után a gyerek tekintetében, és álta- lában nyilván ettól megijednek. És az volt a jó, hogy igyekezett mindenki azt az összeget összeszedni. [...] De ebbe segitségünkre volt egyébként az, egyhárz is, azt meg kell emliteni. Ezeknél a családoknál, abol ez nagyon súlyos probléma volt, sikerült az áramot szabályosan bevezetni.

3) A vonatkozó jogszabályban meghatározott feladatok ellátása, amely feladatok jelentősen bővültek az elmúlt években.

E fő teendőket megismerve, illetve az interjúkban elhangzottak alapján úgy tűnik, a helyi szociális intézményben a kontroll funkció megelőzi a segító funkciót. Különösen kisebb településen gyakran elvárt igény a szociális intézmények dolgozóitól, hogy - ellentétesen a szociális munka szakmai és etikai elveivel - elsősorban egyfajta „szociális rendőrségként" tevékenykedjenek. Helyenként külső nyomásra, helyenként pedig amiatt, mivel a szociális képzések és a gyakorlat alatt sem alakult ki a tényleges segítői attitűd a szakképzettséget szerzők egy részében - ami talán a részidejű, levelező tagozatos képzésekben még gyakoribb - s maguk a dolgozók is azonosulnak e látásmóddal, s ezért a kontrollt a középpontba helyező gyakorlatot érvényesítik. (Bugarszki, 2014) Csakhogy - ahogy azt nemzetközi és hazai tapasztalatok egyaránt jól mutatják (Bugarszki, 2014; Parton és O’Byrne, 2006) - ettől eredmény nem remélhető, az eredménytelenség pedig a szociális területen dolgozók körében gyakori kiégéshez, pályaelhagyáshoz, napjainkra a szociális szakmák súlyos válságához vezetett. (Bugarszki, 2014; Parton és O’Byrne, 2006)

Ahogy a helyi példa is mutatja, e minden résztvevőre - vagyis a kliensekre és a dolgozókra egyaránt - kedvezőtlen hatású munkamódszer az elmúlt 30 év folyamatainak eredményeképpen alakult ki.

Hogy hogyan indult el az intézmény? Nyilván akkor a törvényi elvárásoknak megfelelóen sokkal kevesebb volt a munkánk, mint most [...] Szerintem mi sok olyan munkát is elvégeztünk akkor, ami nekünk nem volt feladatunk, és nem volt munkakörünk abszurde. Több idönk volt egyéb- 
ként a családokra, pedig kevesebb volt a státusz, jóval kevesebb. Többet tudtunk jelen lenni a családok életébe [...] nagyon sokszor ott álltunk mellettük a fazék mellett, és tanitottuk. óket förni [...] Ugye, hogy a 40 órából 20 óra a terep, de mi 35 orát sokszor, meg 40-et is sokszor, meg munkaidón túl is, meg bétvégén is, tehát mi terepen voltunk. Nagyon-nagyon sziviügyünknek tekintettük, és nagyon akartunk segiteni, meg bát úgy tudtuk ókeet megismerni, ha minél többet jelen voltunk velük [...] rendezvényeiken, születésnap, kereszteló, tehát ezelk érdekesek, pláne a romáknál egy-egy lagzi, bivatalosak is voltunk [...] És én eqt, nagyon örülttem, nagyon szerettem csinálni. Én alig vártam, hogy reggel legyen sæó szerint, hogy üjra jöhessek [...] Engem ez tartott életben, mert én nem éreztem itt jól magam, nekem hatalmas volt az ür, a szakadék, tebát amit ott éltem meg, meg ahogy ott éltem (Nyíregyházán - értelmező közbevetés a szerzőtől.) [...] Ažtán én jelentkętem a föiskolára, mert ugye a 2001-es törvény már elö is irta, hogy akik benne dolgoznak, ngye megkapják azt az idöszakot, felmentést, míg el nem végzik, de ugye már nem lebetett [...] betölteni középfokú végzettséggel. Én nem bántam meg [...] én ažt éreztem akekor, 29 évesen, hogy én, amikor én ott hallgattam az ottani oktatókat, én éreztem, hogy jó belyen vagyok [...] Mivel már benne voltam, és átláttam, hogy mit fogok csinálni, tehát igy együtt az nekem egy nagyon-nagyon szép idószak volt. És akkor jött egy mókuskerék.

E megélt és elmesélt folyamatnak az elemző értékelése talán külön tanulmányt érdemelne. Jól látható, hogy a fiatal, képzettség nélküli segítô, az akkori jogszabály adta tág keretek között a helyi szükségletekhez, igényekhez igazodó, valós segítséget jelentő szociális munkát végzett (mégha az elmélet és a pontos módszertan ismerete nélkül is, de életvilág központú segítői beavatkozást (Thirsch, in Sárkány, 2011), jelenlét típusú szociális munkát (MMSZ, 2019). Méghozzá úgy, hogy az a szociális munka szakmai és etikai alapelveinek is maximálisan megfelelt. Aztán részt vesz egy szakmai képzésben, közben a folyamatosan változó vonatkozó jogszabályok, szakmai protokollok egyre pontosabban írják le, mi egy családsegítő feladata (vagyis a szol- gáltatási rendszer a menedzserizmus irányába mozdul el). (Temesváry, 2018) Eközben az intézmény létszáma jelentôsen bővül, s a helyi beavatkozások a segítésről elsődlegesen a kontroll irányába mozdulnak. Ennek az országosan széles körben tetten érhetô folyamatnak (Bugarszki, 2014) az egyik oka vélhetően az lehet, hogy az elmúlt időszak valóban súlyos szakmai és emberi mulasztásaiból eredően példának okáért a veszélyeztetett, emiatt védelembe vett gyermeket/gyermekeket nevelő családok családsegítői meglátogatásának és/vagy a szükséges gyermekvédelmi beavatkozások megtételének a hónapokon keresztüli elmaradása miatt - felsorolhatatlanul sok gyermektragédia (a gyermek, gyermekek súlyos testi és lelki károsodása, halála) történt. Legalább részben ezek miatt a jogalkotó meg kívánja határozni, melyek azok a minimum elvárások, amelyeket egy családsegítőnek meg kell tennie annak érdekében, hogy a családban élő gyermekek alapvető biztonsága ne kerüljön veszélybe. Ennek azonban az lesz a következménye, hogy a benne dolgozó szakemberek egy jelentôs része már csak e minimumfeladatok ellátását, elsősorban a családok kontrollálását tekinti feladatának („Sžerintem sok olyat dolgot megtettünk, ami nem volt feladatunk."), a tényleges segítői munka pedig háttérbe szorul. Valós segítség nélkül viszont a halmozottan hátrányos helyzetú családok nem képesek javítani helyzetükön... És ezzel a(z ördögi) kör bezárult.

A napjainkra kialakult helyzetről a helyben aktív segitői munkát végző, s a későbbiekben bemutatandó eredményeket is felmutató diakónus (62 éves férfi) az alábbi tapasztalatait fogalmazta meg: „Úgy tünt, amikor elkędtem ezt a munkát, hogy cserbenhagyták itt a roma lakosságot [...] Nekem nagyon az, tünik még most is, hogy akinek a feladata lenne ez. hivatalból, amit számonkérnek tólïk azt teljesitik, a többlet pedig lemarad, elmarad. Ebböl az egész történetböl az emberi egymással foglalkozás szinte alig tapasztalható. Ha mindig jogszabályok szerint megyünk, hogy nézzü̈k, hogy egy-egy családba 
mi a probléma, jó, bát ez is segitség, hogy felhivjuk rá a figyelmét, hogy ki kell takaritani, meg legyen egy rubásszekrényed, de bogy ettól többet nem segitenek [...] a belyi illetékes személyek, én ezzel szembesültem. És ak.kor eldöntöttem, hogy én tényleg beleállok ebbe a munkába."

Arról, hogy miben látja ennek az okait a következőket mondta:

„Lehet, hogy most már az emberiség oda jutott, hogy annyira féltem a családomat, meg annyira féltem magam, hogy tovább nem is látok. Én Dorogon látom ezt a fajta, mert tényleg jó dolgos emberek, igyekszenek, de úgy a másik. emberhez, való odafordulás, hát, biztos találhatnánk olyan településeket, abol jobban megy ez a dolog."

Azt, hogy a romák helyzete már jelenleg is kedvezőtlen következményekkel jár a település egésze tekintetében, s hogy e helyzet - adekvát, hatásosabb segítő beavatkozások nélkül - hosszabb távon tovább romolhat, a megkérdezettek többsége helyi szinten már érzékeli. Látják, hogy a nyomorban ragadt, kilátástalan helyzetú roma családok, amelyekben gyakori az alkohol mértéktelen fogyasztása, s megjelent az önsorspusztító „herbálozás" is, önmagukon kívül a közösség egészére is veszélyt jelenthetnek. Városvezetési, szociális szolgáltatási szinten egyaránt látják, helyi egyházvezetési szinten pedig már korábban felismerték, hogy másfajta, érdemi eredményt hozó beavatkozásokra van szükség. A család- és gyermekjóléti szolgálat munkatársa (49 éves nő) szintén megfogalmazta, hogy szerinte milyen beavatkozás hozhat változást, különösen a roma családokban élő gyermekek jelen helyzetből való kimozdításának vonatkozásában. „Ugye nekünk, a velük dolgozó szakembereknek, tehát úgy a pedagógusoknak, mint a gyermekvédóknek kellene közösen [...] gondolkodni [...] felzárkóztató programokat, felvilágositó elöadásokat tartani sokkal többet, mint amire kapacitás van. [...] Egy ilyen közööségszervezódésnek is muszáj lenne, hogy létrejöjöon, hogy mondjuk a roma sұülökekel együtt, akár pedagógusok, akár mi szociális szakemberek, egy ilyen közösségi bázba mondjuk megmutassuk nekik art, hogy együtt fözzünk, vagy együtt süssünk. Vagy bármi olyat, hogy megmutassuk, hogy ez egy jó dolog, és mondjuk te, mint roma lány ezt tanulhatnád, és akekor lenne belöled egy ilyen jó szakács, vagy cukerász és akker el tudnál helyezkedni. [...] Azért is öruilök ennek a szegregációs fel láarkóżtató pályázatnak, mert ebben lesz. közösségi ház, és ott ugye megvalósulhatnak például ezeek a dolgok, hogy megmutassuk nekik, hogy hogyan kell mosni, hogyan kell vasalni, hogyan kell fö:2ni, hogyan kell gyereket nevelni, hogyan kell megsütni egy süteményt, tehát hogy együ̈t próbáljuk bennük megteremteni az. igényt. De amikor ök hazamennek, és abba a családi milióbe, abba a szocializációba, amibe felnóttek, ez. nagyon hamar visszabízza öket."

Látható, hogy a megkérdezett szociális munkás jelentôs részben az intézmény indulásának időszakában alkalmazott beavatkozási módhoz hasonló tevékenyégek végzésétől vár eredményt. Azonban lényeges különbség, hogy míg a korai időkben a humán ökológiai szemléletnek megfelelően (Soós, 2018), a családok otthonában történt ez a munka, a jövőben egy közösségi házban fog megvalósulni. Bár vélhetően ettôl is remélhetôk eredmények, az ezzel kapcsolatos fó problémát utolsó idézett mondatában interjúalanyunk is megfogalmazta. Ugyanakkor úgy véli, erre akkor lesz tényleges lehetőség, ha a helyi szegregátumokat érintő (már elnyert) egyik pályázati projekt keretében, kifejezetten a programban lévők segítésére, további szociális munkásokat vesznek fel, mivel - ahogy arról a korábbiakban szó esett - az egyéb fő feladataik miatt, a jelenlegi munkatársak kapacitásainak jó része lekötött.

\section{A romák helyzetét javító beavatkozások}

Az elmúlt években elindultak olyan országos, helyi egyházi, önkormányzati, valamint önkormányzati intézményi kezdeményezések, amelyek a hátrányos helyzetű emberek, köztük a romák helyzetének a javítására irányultak: 
1) Ahogy a korábbiakban arról már írtam, a közmunkaprogram - igaz, csupán a legalapvetőbb szinten - de hozzájárul e családok anyagi biztonságához, a helyben kiemelten fontos mezőgazdasági munkavégzéssel kapcsolatos ismereteik bővüléséhez, sőt, a roma és a nem roma lakosok közötti kapcsolatok erősödéséhez is. Ugyanakkor volt olyan interjúalanyunk, aki ezt a kapcsolaterősödést alapvetően kedvezőtlennek ítélte amiatt, mivel az elmúlt időszakban megjelenő vegyes párkapcsolatok kapcsán , ,...] az a tapasztalat, hogy az a nem roma származású illetó lecsúszik a romák elvárásaiboz:" (49 éves nố, szociális munkás)

2) A helyi görög-katolikus egyházhoz a problémakezelés érdekében hat évvel ezelőtt egy olyan diakónus csatlakozott, akinek a roma pasztoráció a fó feladata. Ennek keretében - jelenlét típusú szociális munkát végezve (MMSZ, 2019) - a roma közösség segitése érdekében mindennap kijár a szegregátumba. E munkát végző diakónus egyik első feladatának azt tartotta, hogy megismerkedjen a romákkal, s hogy elfogadják őt nem roma emberként valódi segítőnek. A korábbiakban leírt roma - nem roma viszony miatt, amiatt, ahogy a romák ezt megélték, megélik, ez nem volt egyszerú. „Ök nyilván úgy itélike meg, hogy el vannak nyomva, szegregálva vannak $[. .$.$] mindenhonnan csak a rosszat kapják.$ Ennek is megvan az oka [...] nem mindegy, hogy egy városon belül milyen vezetés van, milyen a családsegitó munkája, mert ök velük találkoznak, a polgármesteri bivatal, meg a családsegitó, meg a pap bácsi, maximum az iskola. Ha innen mindenhonnan negativv visszajelzéseket, negativ eróket kapnak, akkor milyen is lehet a véleménye."

A korábbiakban leírt nyomorúságos helyzet miatt, az első feladatok közé tartozott a családok adományokkal való segítése, amely tevékenységet azóta is végzik. Ugyanakkor e családok lelki erejének, ezáltal ezen roma emberek személyiségének fejlesztését tűzték ki elsődleges, az életük jobbá válását eredményező célnak. „Legyen bite az életben, önmagában is bizzon [...] hogy a gyermekemet felneveljem
[...] Ha ebben nem segitjük óket, ha eqt elhagyjuk, akkor nincs felzárkózás." (62 éves férfi, diakónus)

E fejlesztő célú, életvilág központú (Thirsch, in Sárkány 2011) segítő munkához elengedhetetlen a napi szintű jelenlét, ha szükséges este, hétvégén is. Elengedhetetlen továbbá a közös tevékenykedés, a feladatok közös megoldása. Erre példaként a diakónus (62 éves férfi) az alábbi, az adott család életében meghatározó eseményt ismertette: „Amikor adódik egy szituáció, egy helyzet, hogy ą̧t gyorsan meg kell oldani [...] Odatelefonált este 9-kor tavaly, hogy, ,Pap bácsi nagyon nagy baj van [...] csorog befele a plafonon a viz [...] jöjjön ki, nézze meg." Hát mondom, jól van [...] kimentünk [...] tényleg csorgott [...] nem volt katasztrófabelyzet [...] Másnap ezt nagyon gyorsan megoldottuk. Találtam egy roma embert, akinek jó kézü̈gyessége van, és szereztem hozzá palát, lécet, meg ami kellett, és egy-két nap alatt megoldottuk a problémát. De hogy ha én a szép kényelmes fotelböl åt mondom, hát nincs ennek értelme, akkor lehet, hogy [...] már nem is lenne rajta tetö. Ennek a munkának itt látom a szépsééét, meg hát nyilván az értékét. Ez̧ rangsorolni, felsorolni, hogy lesz-e ennek? Tehát emberség kérdése."

A segítségnyújtás ugyanakkor nagyon hosszú, fáradtságos munka, ami gyakran csak évek, évtizedek alatt vezet eredményre. Ennek kapcsán példaként megemlítette diakónus interjúalanyunk, hogy korábban egy alkalommal munkaerôtoborzó céget hívtak ki a romákhoz, akik közül több mint húszan el is jöttek. Azonban hamar kiderült, hogy az írni, olvasni sem tudó roma emberek sajnálatosan nem alkalmazhatóak gyári munkára, bonyolult és veszélyes gépek üzemeltetésére, példának okáért a veszély feliratot sem tudják elolvasni. Ugyanakkor, részben a segítő beavatkozások révén elért jelentős eredménynek tekinthetô, hogy napjainkra a munka nélkül, támogatásokból élő helyi romák csoportja egyre kisebb, sokan alkalmi és idénymunkákat, egyre többen pedig állandó munkát tudnak vállalni.

A helyi parókus (52 éves férfi) az egyházi segítői munka kapcsán úgy fogalmazott, hogy az elengedhetetlen anyagi segítség mellett, amit 
nyújtanak, kiemelten fontosnak tartja a roma földprogramot. Ennek keretében vetőmagot biztosítanak a szegregátumokban élő családoknak, felszántják a kertjeiket, aminek eredményeképpen több helyi család ma már igyekszik, gondozza a kiskertjét, élelmiszert termel magának. Legalább ugyanennyire fontos tevékenységük a ,[...] tanitás, a nevelés, a lelki gondozás [...] hogy érezzéke, hogy ide tartoznak.” (52 éves férfi, lelkész) Úgy tapasztalják, hogy ennek az első eredményei már láthatóak: a romák egyre nagyobb számban vesznek részt szentmiséken, keresztelik meg gyermekeiket, vagy kérnek egyházi temetést. Úgy tapasztalják, sikerült szoros, együttműködő kapcsolatot kiépíteni a helyi romák többségével.

Szintén kiemelten fontosnak tarják az egyház szerepét a roma és a nem roma közösség kapcsolatának erôsítésében. Fontos, napjainkra jelentős részben már megvalósult cél egy olyan egyházközösség kiépítése, amelybe romák és nem romák egyaránt beletartoznak. Ennek egyik - de nem egyetlen - példája, hogy templombúcsú idején ma már a roma hívek is részt vesznek a közös ebéden és a közös ünneplésben. Bár az első évben voltak problémák, de ma már nincsenek, és a nem roma lakosság is megtapasztalta, hogy a romák is tudnak „megfelelöen ünnepelni.”

További hosszabb távú célként egy roma közösségi ház kialakítását tervezik. Úgy vélik, annak működtetésével a hitélet és a közösség tovább erôsíthetô. Ez pedig azért kiemeltem fontos, mert: „Kell egy biztos talaj, amin el tudnak indulni. Ezt a talajt szeretnénk a lábuk alá adni azzal a bittel, amibe lehet kapaszkodni." (52 éves férfi, lelkész)

3) A település polgármestere, s két másik interjúalany is kiemelte, hogy az egyik szegregátum mellett múködő óvodának, ezen belül az ottani óvodapedagógusoknak kulcsszerepe volt abban, hogy az ebben a szegregátumban éló romák helyzete jelentôsen javult az elmúlt években. Az önkormányzat jelentős forrásokat fordított arra, hogy a tárgyi feltételek megfelelőek legyenek. Az épületet felújították, s a szép környezet önmagában példaként szolgál. Ugyanakkor a helyi óvodapedagógusoknak a gyermekeken keresztül sikerült megszólítani a szülőket is. Ez is hozzájárult ahhoz, hogy az itt élők jelentős része ma már rendszeresen dolgozik, egyre inkább odafigyel gyermeke nevelésére, saját lakókörnyezete rendben tartására is.

4) A települési önkormányzat egyik fontos célja a hátrányos helyzetú családok lakhatásának a segítése. Ennek érdekében az önkormányzat a város üresen álló házai közül évente kettőt-hármat megvásárol, s azokat szociális alapon, havi 10.000 Ft bérleti dijért hátrányos helyzetû családoknak adja bérbe. Erre a hátrányos helyzetû családok pályázhatnak. A bérbeadás további feltétele, hogy a család gondozza az udvart és a kertet (ezáltal az üresen álló porták rendben tartása is megoldódik), valamint a család kössön havi 20.000 Ft-ért lakástakarék szerződést, a ház értékétől függő́en hat, vagy nyolc évre. Ennek a letelte után a bérbe vett házat megvásárolhatja. A vételárba az addigi bérleti díjat is beszámítják. Emellett az önkormányzat azt is vállalta, hogy a lakás-elôtakarékossági szerződések kapcsán korábban létezett, mára megszűnt állami támogatás összegével - legfeljebb 400.000 Ft-tal - a szerződők megtakarításait kiegészíti. A családok által megvásárolt lakások árából pedig e programot kívánják folytatni.

5) A polgármester, valamint a megkérdezett szociális szakember a romák helyzetének javulását elsősorban egy már kidolgozott, pályázati úton finanszírozott, két elemből álló deszegregációs projekttől várja. Ennek kapcsán a település vezetôje elmondta, hogy a helyi önkormányzat irányításával, de a család- és gyermekjóléti szolgálat, a gyámügy, a polgárőrség összefogásával összeállítottak egy komplex fejlesztési programot, s elnyertek két egymással összefüggő fejlesztési, illetve prog- 
rammegvalósítási pályázatot, amelyek a szegregátumokban élő családok életkörülményeinek, életlehetôségeinek a javítását célozzák. E komplex projekt keretében esélyközpontot hoznak létre. Ehhez megvásároltak két épületet, az egyikben olyan közösségi teret alakítanak ki, amelyben mosási, tisztálkodási lehetôség lesz, amit a gyakran fürdőszobával sem rendelkezô családok csekély térítés ellenében tudnak majd igénybe venni. A másik pedig krízislakásként fog funkcionálni. E program fontos elemeként sportpályát, közösségi kertet alakítanak ki, valamint a valós helyi igényekre építve szakképzéseket kívánnak nyújtani a helyieknek, akik kertészeti, fakitermelő és parkgondozó képzésekben részesülhetnek. A program egyik legfontosabbnak tartott eleme további fejlesztő és segítő szakemberek alkalmazása, akik napi rendszerességgel segithetik az ott élőket, folyamatosan figyelnek a képzésekben résztvevőkre, arra, hogy elvégezzék a megkezdett tanfolyamot.

Azt, hogy a polgármesternek (48 éves férfi) valós tapasztalatai és kelló ismerete van a halmozottan hátrányos helyzetű családok megsegítése kapcsán, jól jelzi azon - egyébiránt az életvilágközpontú szociális segítségnyújtás szemléletének megfelelő (Thirsch, in Sárkány, 2011) - mondata, miszerint: „Ezekkel a családokeal tíréves intervallumokban lehet eredményt elérni. Tizéves folyamatos munka, együttmüködés kell a felzárkóztatáshoz:"

A megkérdezett szociális szakember (49 éves nő) is hangsúlyozta, hogy a család- és gyermekjóléti szolgálat kiemelt együttmúködő konzorciumi partner a programban, s a megvalósítandó tevékenységek körét az alábbiakban összegezte: „Egy állandó 160 fövel kell eq̣t nekünk megvalósitani, és 16 éven felüli szemébyekkel, ami a tankötelezettségi kor felé irányul. Ez legföbbképpen a képrések [...] próbáltuk itt a belyi viszonyokboz [...] hogy miben tudnák öket foglalkoztatni ... Emellett lesz nagyon sok szabadidös tevékenység [...] lesznek családi délutánok, tebát ilyen együtt fö̌és, sport [...] akár egy futballmérkö̌zés [...] Lesznek benne ilyen jóvátételi programok, ahol obyan fiatalkorúaknak, akik mondjuk pártfogói felügyelet alatt vannak, akkor azoknak szülkséges balgondozás, vagy egy játszótér rendbetétele, vagy egy idösebb embernél lenyírja a füvet, vagy a kapu elött elsepreget. Illetve lesz. ilyen, hogy börtönlátogatás, ugye ez. ilyen elrettentésképpen, tehát oda fogunk vinni fiatalkorúakat [...] (Az, hogy az „elrettentés” a szociális munkában alkalmazható, alkalmazandó prevenciós módszer-e, meglehetôsen vitatott kérdés. Elrettentésre alapuló prevenciós módszerek alkalmazása elsősorban a rendőri, példának okáért az észak-németországi rendőri gyakorlatot jellemzi.)

Lesznek még olyan szabadidös tevékenységek [...], hogy tenisz, tehát asżtalitenisz, akekor zene. Ezt legföképpen a közösségi bázba mindenképpen szeretnénk, egy kollegánk, aki zenész is másodállásba, tehát hogy tánc, zene ez azért lenne, hogy mindenképpen hasznosan töltsék el a gyerekek a szabadidejüket. Illetve szurröprogramok is vannak betervezve [...] A projekt az kér egyéni fejlesżtési terveket is, ugye adva az adott egyénre, és ehbez szociális munkások kellenek, tebát másfél éves foglalkoztatásba be kell vonni a projektvezetó, meg a projektkoordinátoron kiwül ugye, akik figyelemmel kisérik az adott személynek az életét, illetve arra ösztönzilk, hogy benne maradjon a programba."

E számos településen már létező, folyamatban lévő deszegrációs programok sikere - ahogy azt saját kutatásaink során is tapasztaltuk - döntően a benne dolgozó szakembereken múlik. Azon, hogy kellő szaktudással, még inkább kellő szakmai attitűddel, empátiával, türelemmel és valós segitőkészséggel, „életvilág központúan” végzik-e, vagy éppen ténylegesen nem, vagy csak alig, inkább „csak papíron” végzik e munkát. A kulcskérdés tehát leginkább az, sikerül-e megfelelően felkészült és motivált, a roma lakosokat valóban, rogersi értelemben „feltétel nélkül elfogadó”, irántuk nyitott szakembereket bevonni a programba. (Rogers, 2017) S hogy ez miért kiemelten fontos, arról a megkérdezett szociális szakember és a diakónus a következőket mondta: Én szoktam mondani, hogy az önérzeten kivül ök egyébként olyanok, mint a gyerekek, bogy nagyon hamar megérzile azt, hogy ki az, aki nem 
szereti öket, vagy nem fogadja el [...] És sajnos akkor támadásba lendïlnek, de ott már ugye egy bizalmi kapcsolatot nem lehet felépiteni, s beindul a védekerzés, és esetleg konfliktushoz, vezethet. (49 éves nő, szociális munkás) „Csakbogy ök megérzile az ilyen véleményeket, hogy: „Nem érdemes veletek, mert ti úgyis az alja népek, vagytok, tehát semmi értelme veletek." Érdekes módon kiszürik, egyböl meglátják azon az emberen." (62 éves férfi, diakónus)

Ugyanakkor - ahogy azt több interjúalanyunk is megfogalmazta - az elôitéletek leküzdésének, és ezáltal az eredményesebb integrációnak fontos, sőt, talán a legfontosabb eszköze a valóban integrált oktatás megvalósítása lenne. „Egy egységes, integrált iskola sokat segithetne ezen. Például a mintakövetés által." (20 éves férfi, egyetemi hallgató)

A tanulmány elkészitésébez szüleséges kutatómunka az. EFOP-3.4.3-16-2016-00021, A Debreceni Egyetem fejlesztése a felsöfokú oktatás minöségének és hozzáférbetöségének együttes javitása érdekében" címü projekt támogatásával valósult meg.

\section{Irodalom}

Albert, F., Dávid, B. (2018): Interpersonal relationships in Hungary - an over-view. In. Metszetek Társadalomtudományi Folyóirat, 7/2. 72-93.

Bugarszki, Z. (2014): A magyarországi szociális munka válsága. In. Esély, XXVI/3, 64-73.

Bálint, L., Obádovics, C. (2018): Belföldi vándorlás. In. Monostori Judit - Öri Péter - Spéder Zsolt (szerk.): Demográfiai portré 2018. Jelentés a magyar népesség helyzetéröl. Budapest: KSH Népességtudományi Kutatóintézet. 217-236.

Babbie, E. (1996): A társadalomtudományi kutatás gyakorlata. Budapest: Balassi Kiadó.

Europien Bank for Recontruction end Development (EBRD) (2019): Transicion Report 2019-20. web: https://www.ebrd.com/transition-report2019-20 (Letöltés: 2019.12.10.)
Falus, I. (szerk.) (é.n.): Bevezetés a pedagógiai kutatás módszereibe. Budapest: Mũszaki Könyvkiadó Kft,

Forgas, J. P. (2007): A társas érintkezés pszichológiája. Budapest: Kairos.

Gödri, I. (2018): Nemzetközi vándorlás. In. Monostori J.,Öri P., Spéder Zs. (szerk.): Demográfiai portré 2018. Jelentés a magyar népesség helyzetéról. Budapest: KSH Népességtudományi Kutatóintézet. 237-270.

Kapitány, B., Spéder, Z. (2018). Gyermekvállalás. In. Monostori J., Öri P., Spéder Zs.(szerk.): Demográfiai portré 2018. Jelentés a magyar népesség helyzetéról. Budapest: KSH Népességtudományi Kutatóintézet. 47-64.

Komoróczy, G. (1971) (szerk.): Hajdúdorog története. Hajdú-Bihar Megyei Múzeumok Közleményei. 13. Hajdúdorog: Hajdúdorog Községi Tanácsának Végrehajtó Bizottsága

Lannert, J. (2018): Nem gyermeknek való vidék. A magyar oktatás és a 21. századi kihívások. In: Kolosi, T., Tóth I., G. (szerk.): Társadalmi Riport 2018. Budapest: TÁRKI, 167-185.

Magyar Máltai Szeretetszolgálat (MMSZ) (2020): Jelenlét program. https://jelenlet.maltai.hu/ (Letöltve: 2020.01.04.)

Maslow, A., H., (1970): Motivation and personality. (2nd edition), New York: Harper and Row

Parton, N., O’Byrne, P. (2006): Mi a konstruktív szociális munka? In. Esély, XVIII/1, 47-66.

Rákó, E. (2017): A gyermekjólét-gyermekvédelem és a gyermekszegénység aktuális kérdései. In Rákó, E., Soós, Zs. (szerk.): Kibivásoke és válaszok. Tanulmányok a szociálpedagógia területéról. Debrecen: Debreceni Egyetemi Kiadó. 136-147.

Rogers, C. R. (2019): Valakivé válni - A személyiség születése. Budapest: EDGE $2000 \mathrm{Kft}$.

Sárkány, P. (2011): Szociálpedagógiai elméletek. Paidea könyvek. Budapest: Jel kiadó.

Soós, Zs. (2005): A sqociális munka alapjai. Pécs: Comenius Bt.

Soós, Zs. (2009): Reform után. A kistérségi közszolgáltatási reform hatásai a Téti kistérség 
szociális szolgáltatási rendszerére. Esély, XX/1. $71-100$.

Soós, Zs. (2018): Szociális esetmunka. Debrecen: Debreceni Egyetemi Kiadó

Szociális Szakmai Szövetség (3Sz) (2016): A szociális munka etikai kódexe. Budapest: $3 \mathrm{Sz}$

Temesváry, Z. (2018): A szociális munka és a szociálpedagógia modern elméletei. Budapest: L'Harmat$\tan$

Topor, I: A tizenöt éves háború (1591 - 1606) története a Bocskai-szabadságharc kezdetéig. Korok - online folyóirat. Letöltés: 2019. 07. 11 web:

https://korok.webnode.hu/products/toporistvan-a-tizenot-eves-haboru-1591-1606tortenete-a-bocskai-szabadsagharc-kezdeteig/.
Felhasznált jogszabályok

1993. évi III. tv. a szociális igazgatásról és szociális ellátásokról

Felhasznált statisztikai adatbázis

Központi Statisztikai Hivatal (KSH) (2019): Területi Statisztika: Népesség, népmozgalom. Budapest: KSH

Felhasznált dokumentumfilm

Biczó, G., Szabó, H. (2019): Kisvilágok 3, dokumentumfilm-sorozat: Hajdúdorog: Legyen hited élethez. 